\title{
Provenances of Early Printed Books from the Library of the Berdychiv Monastery of Discalced Carmelites
}

\begin{abstract}
The publication presents a source study review of the provenances of the early printed books from the library of the Berdychiv Monastery of Discalced Carmelites, which functioned from the $17^{\text {th }}$ up to the first half of the $19^{\text {th }}$ century. Nowadays the historical collection "The Library of the Berdychiv Monastery of Discalced Carmelites" is preserved in the V.I. Vernadsky National Library of Ukraine, it amounts to 4852 volumes and is the largest one among the book collections of the Roman Catholic monasteries, which are stored in the libraries in Ukraine. The article emphasizes the importance of source studies and the role of provenances in the historical library science research. The main types of provenances (handwritten notes, exlibrises, superexlibrises, seals), found in the books of the Berdychiv collection are presented, and their informative content is highlighted in relation to the ways of reconstruction of the monastic book collection.
\end{abstract}

Key words: provenances - exlibrises - superexlibrises - Berdychiv Monastery of Discalced Carmelites - monastic libraries.

„Z Badań nad Książką i Księgozbiorami Historycznymi” - Udział zagranicznych recenzentów w ocenie publikacji; Stworzenie anglojęzycznej wersji wydawniczej publikacji; Digitalizacja tomów archiwalnych rocznika w celu zapewnienia otwartego dostępu do nich przez Internet oraz wdrożenie i utrzymanie cyfrowej platformy redakcyjnej - zadanie finansowane w ramach umowy $\mathrm{nr}$ 653/P-DUN/2019 ze środków Ministra Nauki i Szkolnictwa Wyższego przeznaczonych na działalność upowszechniającą naukę. 
The books coming from former monastic libraries are a very important source for studies on the organization and activity of these libraries in the past. Provenance records, exlibrises, superexlibrises, seals and marginalia preserved in early printed books offer valuable information about methods of collecting books - purchases and book donations for monasteries, realized by (among others) the authors and patrons of the convents. They also include biographical data of the monks and illustrate a relation between a monk and a book. Therefore they are extremely valuable material for researchers of old book culture, particularly in regard to dissemination, circulation, and reading of detailed works, as well as book patronage. Provenance material reflects also a history of monastic libraries, as well as the monasteries themselves.

Issues and methods of provenance studies on book collections at the territory of former Republic of Poland were discussed by many Polish researchers, among others Barbara Bieńkowska, Maria Cubrzyńska-Leonarczyk, Alodia Kawecka-Gryczowa, Bronisław Kocowski, Józef Adam Kosiński, Maria Pidłypczak-Majerowicz, Kazimierz Piekarski, Maria Sipayłło, Maria Strutyńska, Arkadiusz Wagner ${ }^{1}$, as well as the Ukrainians, like: Natalia Bondar, Ludmiła Denysko, Iryna Kachur². This article is a part of this legacy and re-

1 B. Bieńkowska, Kilka uwag i propozycji w sprawie badań księgozbiorów historycz nych, "Studia o Książce" 1986, vol. 16, pp. 3-31; M. Cubrzyńska-Leonarczyk, Polskie superekslibrisy XVI-XVIII wieku w zbiorach Biblioteki Uniwersyteckiej w Warszawie. Centuria druga, Warszawa 2001; A. Kawecka-Gryczowa, Biblioteka ostatniego Jagiellona. Pomnik kultury renesansowej, Wrocław 1988; B. Kocowski, Zadania i metody badań proweniencyjnych w zakresie starych druków, "Przegląd Biblioteczny" 1951, no. 1-2, pp. 72-84; J.A. Kosiński, Propozycja do instrukcji kartoteki proweniencyjnej starych druków, oprac. M. Pidłypczak-Majerowicz, [in:] Krajobrazy przeszłości. Księga ofiarowana doktorowi Adolfowi Juzwence w siedemdziesiąta rocznicę urodzin, ed. by M. Dworsatschek, Wrocław 2009, pp. 223-239; M. Pidłypczak-Majerowicz, Badania proweniencyjne w bibliotekach kościelnych, "Fides. Biuletyn Bibliotek Kościelnych" 2014, vol. 20, no. 1, pp. 3-13; K. Piekarski, O zadania i metody badań proweniencyjnych. Marginalia do pracy R. Kotuli «Właściciele rękopisów i starodruków zbiorów Z. Czarneckiego», Kraków 1929 (copy from "Przegląd Biblioteczny" 1929, no. 3); M. Sipayłło, O metodzie badań proweniencyjnych starych druków, "Z Badań nad Polskimi Księgozbiorami Historycznymi” 1975, vol. 1, pp. 9-30; M. Strutyńska, Struktura proweniencyjna zbioru starych druków Biblioteki Uniwersyteckiej w Toruniu. Przewodnik po zespołach. Problemy badawcze i metodologiczne, Torun 1999; A. Wagner, Ekslibris jako dziedzina grafiki w sferze zainteresowań historii sztuki i bibliologii, [in:] Metodologia, metoda i terminologia grafiki i rysunku. Teoria i praktyka, ed. by J. Talbierska, Warszawa 2014, pp. 95-105; tenże, Superekslibris polski. Studium o kulturze bibliofilskiej i sztuce od średniowiecza do połowy XVII wieku, Toruń 2016.

2 N. Bondar, Marginalii kyivskoho vydannia Molytvoslova 1742 roku yak dzherelo do istorii rodu Borozn, "Ukrainska Biohrafistyka" 2008, vol. 4, pp. 82-97; N. Bondar, Proveniencii vilenskykh vydan Yevangeliia 1575 i 1600 rokiv z fondiv Natsionalnoi biblioteky Ukrainy imeni V.I. Vernadskoho yak dzherelo istoryko-knyhoznavchykh doslidzhen, "Visnyk Lvivskoho Universytetu. Seria knyhoznavstvo, bibliotekoznavstvo ta informatsiini tekhnolohii" 2008, vol. 3, pp. 31-37; L.M. Denysko, Avtografy na knyzhkakh u kolekcii ridkisnykh vydan Natsionalnoi biblioteky Ukrainy imeni V.I. Vernadskoho. Kataloh, Kyiv 2007; N. Bondar, Y.K. Rudakova, Knyzhkovi znaky na knyhakh iz kolektsii ridkisnyh vydan Natsionalnoi biblioteky Ukrainy imeni V.I. Vernadskoho. Kataloh, Kyiv 2017; I. Kachur, Marginalni zapysy yak dzherelo doslidzhennia istorii chytatstva Zahidnoi Ukrainy 
fers to provenances from the library of the Berdychiv Monastery of Discalced Carmelites, currently maintained in the Department of Historical Collections (DHC) of the Vernadsky National Library of Ukraine (VNLU).

The Berdychiv Monastery of Discalced Carmelites, called the Fortress of the Blessed Virgin Mary, was founded in 1960 by the Kyiv regional governor Janusz Tyszkiewicz (died 1649). Together with the church of the Immaculate Conception of the Blessed Virgin Mary, Saint Archangel Michael, Saint John the Baptist, and Saint John the Evangelist, the monastery belonged to the Kyiv diocese, later Lutsk-Zhytomyr diocese, and the Polish province of Discalced Carmelites of the Holy Spirit. After the $3^{\text {rd }}$ partition of Poland, together with Carmelite monasteries in Wiśniowiec, Kamieniec Podolski and Kupin, it belonged to the Ruthenian province of the Holy Spirit.

A few studies discuss broadly the history of the library of the Berdychiv Monastery, it is also hardly mentioned in printed sources. Franciszek Radziszewski in his work Wiadomość historyczno-statystyczna o znakomitszych bibliotekach $i$ archiwach... [Historical and statistical information about excellent libraries and archives...] (Kraków 1875) characterizes it in one sentence only: "The library of the former Carmelites monastery, quite numerous"3. Another short information about this library was given by father Benignus Józef Wanat in the monograph Klasztor karmelitów bosych w Berdyczowie na Ukrainie... [The Monastery of Discalced Carmelites in Berdychiv, Ukraine] (Kraków 2007) ${ }^{4}$ :

Edward Chwalewik stated, that after the monastery secularisation in 1870 Tsarist authorities took part of the Berdychiv Discalced Carmelites Monastery library, amounting to 6508 volumes, to the Library of the National Pedagogical Dragomerov [sic!] Institute in Kyiv, which currently can be found in the «Collection» of the Shevchenko National University 5 .

XVIII-XIX st., "Zapysky Lvivskoi Naukovoi Biblioteky im. V. Stefanyka 2008, vol. 1 (16), pp. 3-25; N. Bondar, Marginalni zapysy yak dzherelo doslidzhennia retseptsii frantsuzkoi knyhy v Galychyni u 2-i pol. XVIII st., "Bibliotechnyi Visnyk" 2009, vol. 3, pp. 30-34; N. Bondar, Starodruky z bibliotek sanotskoho dukhovenstva u fondakh Lvivskoi naukovoi biblioteky im. B. Stefanyka NAN Ukrainy, "Zapysky Lvivskoi Naukovoi Biblioteky im. V. Stefanyka" 2007, vol. 15, pp. 3-20; I. Kachur, Z historii bibliotek renesansowych - dar Erazma z Rotterdamu dla arcybiskupa Jana Laskiego, [in:] Książka dawna i jej właściele. Zbiór studiów. Vol. 2, ed. by D. Sidorowicz-Mulak, A. Franczyk-Cegła, Wrocław 2017, pp. 19-34.

3 F. Radziszewski, Wiadomość historyczno-statystyczna o znakomitszych bibliotekach i archiwach publicznych i prywatnych, tak niegdyś bylych jako i obecnie istniejacych w krajach dawna Polskę składajacych, a mianowicie: w Królestwie Polskiem, Galicji, W. Ks. Poznańskiem i Zachodnich guberniach Państwa Rossyjskiego porządkiem abecadłowym miejsc ułożona, Kraków 1875, p. 2.

4 B.J. Wanat, Klasztor karmelitów bosych w Berdyczowie na Ukrainie. Studium monograficzne, Kraków 2007, pp. 112-114.

5 Ibidem, p. 114. 
Factual mistakes in this citation require corrections. The secularisation of the Berdychiv monastery took place not in 1870 , but in $1866^{6}$. Its collection was moved to Kyiv in October 1878, to the Library of the Saint Vladimir Royal University, not to the Library of the National Pedagogical Dragomanov Institute, which was established just in $1926^{7}$.

Earlier, in her work published in Kyiv in 1988, concerning book collections of the VNLU (that time the library was named the Central Scientific Library of the USSR Academy of Sciences), the Ukrainian researcher Eugenia Kolesnyk characterized briefly the Carmelites library, according to the historical and political narration binding of the Soviet state ${ }^{8}$. On the other hand M. Pidłypczak-Majerowicz in her book Biblioteki i bibliotekarstwo zakonne na wschodnich ziemiach Rzeczypospolitej w XVII-XVIII wieku [Monastic libraries and librarianship at eastern territories of Poland in the $17^{\text {th }}$ and $18^{\text {th }}$ centuries] (Wrocław 1996) concerning organization and functioning of monastic libraries mentions the Discalced Carmelites printing house in Berdychiv in regard of typographic activity of Catholic monasteries on Belarussian and Ukrainian territories. The author also mentions one book from the Berdychiv collection edition of Seneka works Opera philosophica (Wenecja 1492) ${ }^{9}$, whereas Urszula Paszkiewicz in her documentary work Cathalogus cathalogorum ... (Warszawa 2015 ) informed about a manuscript catalogue of 1781, and listed documents of general visitation of the monastery of the years 1802 and $1822^{10}$. I. Ciborowska-Rymarowicz referred to this catalogue, publishing in 2017 the article Polonika w księgozbiorze klasztornym karmelitów bosych w Berdyczowie (na

6 State Archive of Zhytomyr Oblast (Derzhavnyi arkhiv Zhytomyrskoi oblasti, Gosudarstvennyi arkhiv Zhytomirskoi oblasti, m. Zhytomyr), f. 178, op. 7, spr. 2452, ch. 29.

7 State Archive of the City of Kyiv (Derzhavnyi arkhiv mista Kyieva), f. 16, op. 316, spr. 139, ch. 20 .

8 Y. Kolesnik, Knizhnyie kollektsii Centralnoi nauchnoi biblioteki Akademii nauk USSR, Kiiev 1988, pp. 40-44; among publications after 1991 see e.g. P. Skavronski, "Berdychivska Kolektsiia" knyg v Natsionalnii Bibliotetsi Ukrainy imeni V.I. Vernadskoho, 14/06/16, [online] http://berdpo. info/news/kraeznavstvo/berdichivska kolektsiya knig v natsionalniy bibliotetsi ukrayini imeni_v_i_vernadskogo-id8774.html [retrieved on 23.06.2018]; I. Ciborowska-Rymarowicz, Marginalni zapysy starodrukiv iz knyhozbiren katolytskykh monastyriv XVI-XVIII st. na etnichnykh ukrainskykh zemliakh yak dzherelo do istorii formuvannia monastyrskykh bibliotechnykh fondiv, "Naukovi Pratsi Natsionalnoi Biblioteky Ukrainy imeni V.I. Vernadskoho" 2010, vol. 28, pp. 266-287; ibidem, Mediievist, 2013, [online] http://www. Medievist.org.ua/2013/03/xvixviii.html [retrieved on 23.06.2018]; I. Ciborowska-Rymarowicz, Dzherela dla doslidzhennia istorii formuvannia fondu knyhozbirni Berdychivskoho monastyria bosykh karmelitiv, "Naukovi Pratsi Natsionalnoi Biblioteky Ukrainy imeni V.I. Vernadskoho" 2016, vol. 44, pp 329-343.

9 M. Pidłypczak-Majerowicz, Biblioteki i bibliotekarstwo zakonne na wschodnich ziemiach Rzeczypospolitej w XVII-XVIII wieku, Wrocław 1996, pp. 39, 88, 172.

10 U. Paszkiewicz, Cathalogus cathalogorum. Inwentarze i katalogi bibliotek z ziem wschodnich Rzeczypospolitej od XVI wieku do 1939 roku. Spis scalony, poprawiony i uzupetniony. Vol. 1, Warszawa 2015, p. 59, no. 50, 51. 
podstawie katalogu z 1781 r.)... ${ }^{11}$ [Polonica in the library of the Berdichyv Monastery of Discalced Carmelites (based on the catalogue of 1781)...].

The Berdychiv library is the largest collection among those of Catholic monasteries preserved in Ukraine. Such a conclusion comes from the studies and explorations realized by the author of the hitherto article in collections of the largest Ukrainian libraries, as well as historical and book studies analysis of publications concerning the history of monastery libraries in Ukraine. The collection maintained in the DHC VNLU amounts to 4852 volumes. A small part of early printed books from Berdychiv belongs to the Department of Early Printed and Rare Books (DEP) VNLU, in the sets of incunabula, paleotypes, Elzevir prints, Latin font prints from the second half of the $16^{\text {th }}$ century to the first quarter of the $19^{\text {th }}$ century.

The library of the Berdychiv monastery was collected through book purchases, gifts, testamentary donations of deceased monks, and completed with prints from the monastery publishing. Main source of information concerning acquisition are provenances, i.e. notes proving belongingness of a copy to the Berdychiv collection. All notes are in Latin. Mostly they take a form of "Conventus Berdiczoviensis Carmelitarum Discalceatorum" inscription, rarely as "Pro Biblioteka Conventus Berdiczoviensis Carmelitarum Discalceatorum" and "Collegii Conventus Berdiczoviensis Carmelitarum Discalceatorum". The entry "Pro Apothekae" can be found on charts of several medical works, which indicates the existence of a subcollection of special purposes, stored apart from the core collection. This is the only provenance entry of that kind. Paper stickers with signature on books spines also confirm that they were the property of the monastery library: Latin letter indicated section, and Arabic cipher - book number in this section. Books from the Carmelites collection are also signed with exlibrises, superexlibrises, and seals as provenances.

A part of provenance entries indicates clearly that these books were previously maintained in other monastic units, i.e. in the Discalced Carmelites monasteries in Wiśniowiec, Kupin, Lviv, Przemyśl, Warsaw, Głebokie (Dzisna county in Vilnius Governorate), residents of this convent in Narodycze (Owrucz county in Wołyń Governorate), as well as the Jesuits' colleges in Lublin and München, the Jesuits' residence in Romanów (Nowogród-Wołyń county in Wołyń Governorate). they were Transferred to Berdychiv probably in exchange or transmission of needed books from other monasteries after 1832.

Another method of development of monastery collections was donations, often by secular persons. The book collection of Stanisław Baczyński,

11 I. Ciborowska-Rymarowicz, Polonika w księgozbiorze klasztornym karmelitów bosych w Berdyczowie (na podstawie katalogu z 1781 r.). Zarys problemu, "Z Badań nad Książką i Księgozbiorami Historycznymi” 2017, special vol.: Polonika w zbiorach obcych, eds. J. Puchalski, A. Chamera-Nowak and D. Pietrzkiewicz, pp. 229-237. 
Owruczarmorer, was a part of the Berdychiv library, donated on April 14, 1772. It is proved by the book of visits of the Berdychiv church and monastery of the year 1841, where documents concerning monastery funds and perpetual bonds are described. The documents are divided into five sets, the fourth one notices: "on April 14, 1772 Stanisław Baczyński donates a library to the monastery"12. The entry "Ex Lib. Stan. Baczyński TOR C Lubl."13 can be found on the books. In gratitude, the Carmelites obliged themselves to celebrate annually in May "an anniversary" - a memorial service for deceased parents and siblings of S. Baczyński, and also for his soul after his death.

The monastic library received also the book collection of unknown Pawel Orzechowski. The entry "Paweł Orzechowski" was found on the pages of approximately 40 books. On one of them probably his superexlibris was placed - "PO" initials stamped on upper facing ${ }^{14}$.

There are also ownership entries of priors and sub-priors of the Berdychiv monastery: father Augustyn of Saint Erasmus (Jan Dłuski, died 1767) - prior in the years 1742-1745 $5^{15}$; father Sebastian of Ressurection - sub-prior in the years 1745-1748 ${ }^{16}$; father Rafał of Saint Cornelius and Saint Cyprian (Michał Walenty Grey; died 1807) - sub-prior 1761-1763 and prior in the years 1790-1793 ${ }^{17}$. An example could also be a copy of the third edition of Rhetorica Explicata Et Applicata Ad Eloquentiam Civilem Et Ecclesiasticam... (Bamberg, Würzburg 1772) by Hermann Goldhagen ${ }^{18}$, with a red wax seal on endpaper, with a badge of the Discalced Carmelites convent, which could belong to a monastery prior or a provincial. There are also the following entries at the title page of this work: "Ex Libris F[ratris] Dionisii a S[ancto] Joanne de Dukla Carmelitae Excalceati 1784" and "Conventus Berdiczoviens[is] Carmelit[arum] Discal[ceatorum] Pr[ovinci]ae Polonae Sancti Spirit[us]". Father Dionizy Ocholiński of Saint John of Dukla (1763-1830) at first was a lecturer of philosophy and theology in the seminary working in the Berdychiv convent. Later he fulfilled different offices: secretary of the province (1800), diocese examiner (1801-1802), definitor (1801-1805, 1806-1808), provincial of the Ruthenian province of the Holy Spirit (1811-1814) ${ }^{19}$ - Berdychiv was at the time residence of the Ruthenian province of the Discalced Carmelites - and a prior of the convent in Wiśniowiec (since 1817).

\footnotetext{
12 B.J. Wanat, Klasztor karmelitów bosych..., p. 109.

DHC, sign. Berd. coll. 103, 384, 386, 1071.

DHC, sign. Berd. coll. "O/13".

B.J. Wanat, Klasztor karmelitów bosych..., pp. 64, 142, 173.

Ibidem, p. 175.

Ibidem, pp. 174, 176, 304, 335.

DHC, sign. Berd. coll. 1002.

B.J. Wanat, Klasztor karmelitów bosych..., pp. 165, 167, 260.
} 
On the other hand, an example of extended ownership entry can be the note on the copy of Sacrorum Bibliorum Vulgatce Editionis Concordantice... (Köln $1684^{20}$ ), written by Aleksander Koziczkowski, pantler of Liw, dated on 1795 and addressed to book recipient, prior of Berdychiv convent father Klementyn of Mother of God from Carmel Mountain - Józef Zaleski (died 1810):

Hic Liber S[acro]rum Biblior[um] Concordantiae / donat[us] est Re[vere]ndissimo Patri

Clementino Zaleski / Priori Con[ven]t[us] Berdiczoviensis Carmelitarum Discal[ceatorum] a Meo D[omi]no Alexandro Felici Ko[zi]czkowski Dapiffero Livoniae Capit[aneo] / Exercitum R[eg]ni [Polo]niae A[n]no 1795 Mensis 30 Julij.

Father Klementyn served as a convent prior in the years 1796-1801, and in the years 1806-1808 he was provincial of the Ruthenian province of the Holy Spirit, seated in Berdychiv ${ }^{21}$.

Interesting are also entries in the books of father Hubert of Virgin Mary Visit, including information about his will to pass them to the Berdychiv monastery after his death. These entries can be found on title pages of 8 volumes. The copy of Jaime de Corelli Praxis Confessionalis... (Augsburg 1757) ${ }^{22}$ has an entry: "P[atri] Fr[at]ris Huberti / a Visit[atione] B[eatissimae] V[irginis] Mariae / Carmelitae Discalceati / applicatur Conventui in quo morior et Oretur pro A[nim] a mea". On the title page of another print Dictionarium casuum conscientiae... by François Morenas and Eusebius Amort (Augsburg 1762) ${ }^{23}$ there is an entry: "P[atri] F[rat]ris Huberti a Visit[atione] Beatissimae V[irginis] Mariae / Carmelitae Excalceati, post mortem applico Conventui / Berdiczoviensi et peto Lectorem S[ancti] Orationes". What is known about father Hubert, that in the years 1766-1777 he was the convent examiner, and in 1777, on behalf of the chapter, he signed employment conditions for the pharmacist Marcinkiewicz in the monastery pharmacy ${ }^{24}$.

A significant number of early printed books include ownership entries indicating their origin from other Carmelite convents. On the endpapers of five out of seven volumes of Tractatus Theologici... (Wenecja 1738) by Charles Witasse, which were moved to Berdychiv from the Discalced Carmelites library in Przemyśl, there is an entry informing about its purchase:

Hic liber emptus est ab Adm[odo] R[evere]ndo N[ostri] Patre / Cherubino / ab Assumptione

$\mathrm{B}$ [eatissimae] V[irginis] M[ariae] Exprovinciali / sub id temporis Priore Conventus Premisliensis / Carmelitarum Discalceatorum / Sumptibus ejusdem Conventus / Anno D[imi]ni 1780.

\footnotetext{
20 Sign. Berd. coll. 1.

21 B.J. Wanat, Klasztor karmelitów bosych..., pp. 167, 174, 335.

22 DHC, sign. Berd. coll. 540.

23 DHC, sign. Berd. coll. 545.

24 B.J. Wanat, Klasztor karmelitów bosych..., pp. 116, 177.
} 
Nine volumes of the Würzburg edition of Summa..., Sive Cursus Theologice... (Würzburg 1767) (25 $^{25}$ baint Thomas Aquinas includes also entries confirming their Przemyśl origin, like the one on the endpaper of volume seven:

Pro Bibliotheca Collegii Premis[liensi] Carmelit[arum] Discal[ceatorum] / Comparat[us] ad usum / Fr[atrum] Studentium Ejusdem Collegii / Opera et Studio A[dmodo] R[everendo] $\mathrm{N}$ [ostri] P[atre] Constantini a B[eatissimae] Kunegundae / protunc Collegii Prioris Premislii / modo vero Definitoris 3-ii actualis.

The Discalced Carmelites monastery together with the church of Saint Theresa in Przemyśl was funded by Podolian governor Marcin Krasicki (1574$1631)$ in 1625 and finished 5 years later. It belonged to the Polish province of the Holy Spirit. By decrees of the Austrian Emperor Joseph II, it was closed in 1784, and given to the Greek Catholics, serving as cathedra of Greek Catholic eparchy of Przemyśl. Books from this convent could have been transferred to Berdychiv after its closing.

Among exlibrises one can select those of the year 1595, with a printed text informing about belongingness of the works to the Jesuits college in München ${ }^{26}$. Interesting is also the exlibris of priest Antoni Borna, Franciscan of Observance, chaplain of princes Radziwiłł, with a text: "Z Xiąg Xdza Antoniego Borny / Z. S. Fr. Obserwantow Kapelana / XX. Radziwiłłow WW. TT." ${ }^{27}$, and exlibris of the Kyiv and Czernichów bishop Józef Andrzej Załuski (1702-1774), with the text: "I.A. ZALUSKI"28. The books with the latter exlibris were probably purchased at auctions of duplicates from the Załuski Library, which had been organized in Warsaw since 1761, or they were donated by the bishop to a prior or the Berdychiv monastery. Five publications with J.A. Załuski exlibris can be found in this book collection.

Heraldic exlibrises can be found on the endpaper of two early printed books - the first one belonged to Konstanty Ludwik Plater (1722-1778) ${ }^{29}$, scribe of Grand Duchy of Lithuania, and the other to an unidentified person, and its text has not been preserved.

A small group of provenance signs in the studied collection consists of superexlibrises. The ownership mark from the $17^{\text {th }}$ century is worth noting, belonging to princes Wiśniowiecki, with their coat of arms Korybut. Books with such an exlibris were in the castle library of Wiśniowiecki family, established by great Lithuanian hetman Michał Serwacy Wiśniowiecki (16801744), benefactor of the Carmelites monastery in Wiśniowiec (Krzemieniec county, Wołyń region). The sign of prices Wiśniowieski has been discussed in

\footnotetext{
25 DHC, sign. Berd. coll. 631: vol. 7-8.

26 DHC, sign. Berd. coll. 37.

27 DHC, sign. Berd. coll. 541.

28 DHC, sign. Berd. coll. 60.

29 DHC, sign. Berd. coll. 253.
} 
book studies, among others in the works of Vincas Kisarauskas ${ }^{30}$, Edmundas Laucevicius ${ }^{31}$ and I. Ciborowska-Rymarowicz ${ }^{32}$. At least the early printed book from the Berdychiv collection - the work of Hegesippus De Bello Ivdaico, Et Vrbis Hierosolymitance excidio libri quinq[ue]... (Köln 1575) ${ }^{33}$, except the Wiśniowiecki family exlibris, was market on the title page also with two ownership entries. The first one proves that earlier, in 1772, the book was donated to the monastery in Wiśniowiec by Stanisław Jerzy Mniszech (1745-1806), the Crown ensign:

Pro Bibliotheca Conventus Visniovecensis Carmelitarum Discalceatorum Ex donatione Illustrissimi Magnifici Domini Stanislai Mniszech Succamerande M[agni] D[ucatis] Litth[uani]. Fundatoris N[ost]ri Munificentissimi A[nno] D[om]ini 1772-do. Oret[ur] pro Eo. and the other confirms books belongingness to the monastery library: "Conventus Visniovecensis Carmelitarum Discalceatorum".

In due time Mniszech aimed to join clerical state, however finally he resigned. Books he donated to the monastery may come from this period, when he was going to sacrifice his life to God and the Church.

There is one more ownership mark in the Berdychiv monastery library, related to the Wiśniowiecki castle library - well-known heraldic exlibris of Michał Jerzy Wandalin Mniszech (1742-1806), Grand Marshall of the Crown ${ }^{34}$. It is a copperplate from after 1780 when the bibliophile was awarded the Saint Andrew the Apostle Order. This Order is presented on this ownership mark together with received earlier orders of Saint Stanislaus? and of the White Eagle. Moreover, the exlibris presents the eagle keeping in talons irregular cartouche with the Kończyc coat of arms of the Mniszech family, and a text "Ex Libris Mich. Comitis Vandalini Mniszech". This mark was placed on two volumes of the Aleksander Gordon work La Vie Du Pape Alexandre VI Et De Son Fils Cesar Borgia (Amsterdam 1751) 35 .

Both volumes went to the Berdychiv library probably toegther with other books from the Discalced Carmelites Monastery in Wiśniowiec. This monastery, together with the church of Saint Anna, was funded by prince Jeremi Wiśniowiecki (1612-1651), the Russian governor. Destroyed by the Turks in

\footnotetext{
30 V. Kisarauskas, Lietuvos knygos ženklai, 1518-1918, Vilnius 1984, p. 53.

1 E. Laucevicius, XV-XVIII a. knygu irišimai Lietuvos bibliotekose, Vilnius 1976, p. 60.

32 I. Ciborowska-Rymarowicz, Rodovi biblioteky Pravoberezhnoi Ukrainy XVIII stolittia (Vyshnevetskykh-Mnishekiv, Pototskykh, Mikoshevskykh: istorychna dola ta suchasnyi stan, Kyiv 2006, p. 64.

DHC, sign. Berd. coll. 1777.

34 W. Wittyg, Ex-libris'y bibliotek polskich XVII i XVIII wieku, Warszawa 1903, pp. 50-51; Pięć wieków ekslibrisu polskiego. Katalog wystawy ze zbiorów Biblioteki Narodowej, elab. by M. Grońska, Warszawa 1973, p. 11; I. Ciborowska-Rymarowicz, Rodovi biblioteky Pravoberezhnoi Ukrainy ..., pp. 68, 92 .

35 DHC, sign. Berd. coll. 2138.
} 
1673, it was rebuilt together with the new church of Saint Michael Archangel by prince Michał Serwacy Wiśniowiecki (1680-1744), hetman of the Great Duchy of Lithuania. It was secularised in 1832 by tsarist authorities, and the monks were transferred to the Berdychiv monastery. Besides the volumes mentioned above, another book from Wiśniowiec came to Berdychiv library probably that time - the 6 volumes edition of Antonio Maria Boranga Institutiones Theologico Dogmatico Canonico Historico Morales... (Venice 1766) ${ }^{36}$ with the entry of title pages of the volumes: "Hic Author emptus est sub Prioratu / A[dmodo] R[everendo] P[atre] N[ostri] / Raphaelis a SS. / Cornelio et Cypriano / pro C[onven]tu Visniovecensi / Carmelit[arum] Discalceatorum / Anno D[omi]ni 1774". The same was with the 3 volume edition of the Dominican Pietro Maria Gazzaniga Praelectiones theologicae de Deo Uno, et Trino... (Venice, 1770) ${ }^{37}$, in which the following entry can be found on a title page of volume 2: "Hoc opus Authore Gazzaiga Emptum est sub Prioratu / A[dmodo] $\mathrm{R}$ [everendo] P[atri] N[ostri] Innocentij a S. Thoma pro Bibliotheca / Conventus Visniovecensis / Carmelitarum Discalceatorum. / Anno D[omi]ni 1778".

The copy of Indices Omnes In D. Thomae Svmmam Theologicam hactenus impressi... (Rome 1619) (R8 $^{38}$ comes from another monastery library, of the Lviv Discalced Carmelites, as proved by the superexlibris of this monastery. There is the Discalced Carmelites emblem on the upper linen of the book - the Carmel Mountain with a cross surrounded by stars; in upper part of cartouche prophet Elias' hand, the convent patron, with a fiery sword; the convent motto on a band: "Zelo zelatus sum pro Domino Deo exercituum", and monastery name aside: CO[NVENTUS] LE[OPOLIENSIS] SA[NCTI] MI[CHAELIS] C[ARMELITARUM] D[ISCALCEATORUM]. There is also the entry on a title page, confirming that the book belonged to the Lviv Discalced Carmelites. The wooden Carmelite monastery and church of Saint Michael Archangel in Lviv were funded in 1613 by Jan Ładochowski (died 1622), castellan of Wołyn ${ }^{39}$. In 1642 the monks moved to a new, brick monastery funded by prince Aleksander

36 DHC, sign. Berd. coll.554: vol. 1-2, vol. 3-4, vol. 5-6.

37 DHC, sign. Berd. coll. 567, vol. 2.

38 DHC, sign. Berd. coll. 41(inv. 2771258).

39 Stanisław Chodyński obviously measleads Jan Ledóchowski, castellan of Wołyń, as a founder of the Lviv Discalced Carmelites, see: X.S.Ch. [rev. S. Chodyński], Karmelici bosi w Polsce, [in:] Encyklopedia kościelna podlug teologicznej encyklopedii Wetzera $i$ Weltego, z licznemi jej dopetnieniami. Vol. 10, published by M. Nowodworski, Warszawa 1877, p. 45; see also A. Boniecki, Herbarz polski. Part 1: Wiadomości historyczno-genealogiczne o rodach szlacheckich. Vol. 14, Warszawa 1911, p. 55, tabl. "Rodowód Halka-Ledóchowskich herbu Szaława linja hrabiowska". Wheras in volume 6 of the Leipzig edition of Herbarz polski of Kasper Niesiecki of 1841 (published by Jan Nepomucen Bobrowicz) there is information that in $1617 \mathrm{r}$. Hieronim Ładochowski, Korczak coat of arms, was a castellan of Wołyn (ibidem, vol. 6, p. 204), although in the 1st volume of this edition Jan Ładochowski, Korczak coat of arms, died in 1622 is mentioned as a castellan of Wołyń in 1617 (ibidem, vol. 1, p. 263). 
from Ostróg Zasławski, Elżbietę Jaćmierską from Mstyczów and Aleksander Kuropatwa; the construction was finished in 1645. In 1781 the monastery was secularised, in 1784 taken over by the Reformates, and after their secularisation in 1789 given to the Carmelites ${ }^{40}$. According to F. Radziszewski, the library of Lviv Discalced Carmelites consisted of up to 4000 printed works (in 6342 volumes) and 368 manuscripts ${ }^{41}$.

Among early printed books from the Berdychiv library, 9 volumes ${ }^{42}$ with the superexlibris of the Discalced Carmelites Monastery in Głębokie were identified, placed in the upper part of a spine of a leather binding ${ }^{43}$. The mark, beside the convent badge, includes an abbreviation of monastery name: C[ONVENTUS] G[LEMBOCENSIS] C[ARMELITARUM] D[ISCALCEATORUM]. On spines of bindings of these books there are also stamps of different letters of Latin alphabet, which could have meant thematic sections, and a unified date in Roman numbers - "MDCCLVIII". This is probably the year where bindings were made. On title pages of these books, there are also entries: "Conventus Glembocensis Carmelitarum Discalceatorum". The monastery in Głębokie, together with the church of the Assumption of Virgin Mary, was founded in 1639 by Józef Korsak (died 1643) Mścisław governor ${ }^{44}$. The library of the monastery in Głębokie amounted in 1796 to 882, in 1830 - 262 ${ }^{45}$, in $1834-$ 2051 units $^{46}$. After its secularisation in 1842, the collection was moved to Vilnius. The rest of the library reached this city in 1864 when the Carmelites were finally forced to leave their monastery ${ }^{47}$. A part of the printings of the Carmelites from Głębokie might have been transferred to Berdychiv just from Vilnius. Currently, early printed books from their collection are dispersed, and can be found in several locations: in the University Library in Vilnius (Vilniaus universiteto biblioteka), the National Library of Belarus, the National Museum of the Arts of the Belarus Republic, and in the VNLU ${ }^{48}$.

\footnotetext{
$40 \quad$ X.S.Ch. [rev. S. Chodyński], Karmelici bosi..., p. 45.

$41 \quad$ F. Radziszewski, Wiadomość historyczno-statystyczna..., p. 43.

42 DHC, sign.: Berd. coll. 355, 887, 894, 896, 1429, 2666; Pal. 1710 (old sign. Berd. coll. 40); DSD, sign.: Pal. 161(1-3), In 4957/1.

43 Superekslibris was published in: V. Kisarauskas, Lietuvos knygos..., p. 48.

44 Stownik geograficzny Królestwa Polskiego i innych krajów słowiańskich. Vol. 2, ed. by F. Sulimierski, B. Chlebowski, W. Walewski, Warszawa 1881, p. 600.

45 J. Kurczewski, Biskupstwo wileńskie od jego założenia do dni obecnych, zawierajace dzieje i prace biskupów i duchowieństwa diecezji wileńskiej, oraz wykaz kosciołów, klasztorów, szkót i zakładów dobroczynnych $i$ społecznych, Wilno 1912, p. 321.

46 U. Paszkiewicz, Cathalogus cathalogorum ..., p. 215.

47 Stownik geograficzny Królestwa Polskiego..., Vol. 2, p. 600.

48 N.Y. Trifonova, O knihakh iz biblioteki Glubokskoho karmelitskoho monastyria v sobranii Natsionalnoho khudozhestvennoho muzeia Respubliki Belarus, [in:] Berkovskiie chteniia. Knizhnaia kultura v kontekstie mezhdunarodnykh kontaktov - 2015. Materialy Mezhdunarodnoi nauchnoi konferentsii. Minsk, 26-27 maia 2015, Minsk-Moskva 2015, pp. 548-551; T.I. Roshchyna, Belaruski
} 
The selection of provenance material presented above proves that the library of the Discalced Carmelites Monastery in Berdychiv is an important monument of culture and history, as the largest historical monastery library preserved in Ukraine. Further studies should be aimed at developing a scientific catalogue of this collection, regarding essential, and sometimes the only available evidence in provenance entries and marks placed on pages and bindings of particular volumes. Analysis of these provenances and the library content will allow presenting its history, as well as the history of the community in which it had been gathered and used.

Translated by Matgorzata Kisilowska

\section{References}

Archival materials

State Archive of the City of Kyiv (Derzhavnyi arkhiv mista Kyieva), f. 16.

State Archive of Zhytomyr Oblast (Derzhavnyi arkhiv Zhytomyrskoi oblasti, Gosudarstvennyi arkhiv Zhytomirskoi oblasti, m. Zhytomir), f. 178.

Literature

Betlej A. , Kościół p.w. św. Michała Archanioła (Nawiedzenia Najśw. Panny Marii) i klasztor OO. Karmelitów Trzewiczkowych (pierwotnie OO. Karmelitów Bosych), [in:] Kościoły i klasztory Lwowa z okresu przedrozbiorowego. [Vol.] 2, elab. by A. Betlej et al., Kraków 2012, pp. 133-170.

Bieńkowska B., Kilka uwag i propozycji w sprawie badań księgozbiorów historycznych, "Studia o Książce" 1986, vol. 16, pp. 3-31.

Bondar N., Marginalii kyivskogh vydannia Molytvoslova 1742 roku yak dzherelo do istorii rodu Borozn, "Ukrainska Biografistyka" 2008, vol. 4, pp. 82-97.

Bondar N., Proveniiencii vilenskykh vydan Yevangeliia 1575 i 1600 rokiv z fondiv Natsionalnoi biblioteky Ukrainy imeni V. I. Vernadskoho yak dzherelo istoryko-knygoznavchykh doslidzhen, "Visnyk Lvivskoho Universytetu. Seriia knyhoznavstvo, bibliotekoznavstvo ta informaciini tekhnologii" 2008, vol. 3, pp. 31-37.

Boniecki A., Herbarz polski. Part 1: Wiadomości historyczno-genealogiczne o rodach szlacheckich. Vol. 14, Warszawa 1911.

Ciborowska-Rymarowicz I., Dzherela dla doslidzhennia istorii formuvannia fondu knyhozbirni Berdychivskoho monastyria bosych karmelitiv, "Naukovi Pratsi Natsionalnoi Biblioteky Ukrainy imeni V. I. Vernadskogo" 2016, vol. 44, pp. 329-343.

superekslibrys: terra incognita, [in:] Zdabytki. Dakumentalnyia pomniki na Belarusi. Vol. 15, Minsk 2013, p. 197; Katalog paleotipov iz fondov Tsentralnoi nauchnoi biblioteki im. V.I. Vernadskogo NAN Ukrainy, ed. M.A. Shamrai, Kiiev 1995, № 319, № 905, № 2108, № 2415. 
Ciborowska-Rymarowicz I., Marginalni zapysy starodrukiv iz knyhozbiren katolytskych monastyriv XVI-XVIII st. na etnichnykh ukrainskikh zemliakh yak dzherelo do istorii formuvannia monastyrskykh bibliotechnykh fondiv, "Naukovi Pratsi Natsionalnoi Biblioteky Ukrainy imeni V. I. Vernadskogo" 2010, vol. 28, pp. 266-287.

Ciborowska-Rymarowicz I., Marginalni zapysy starodrukiv iz knyhozbiren katolytskykh monastyriv XVI-XVIII st. na etnichnykh ukrainskikh zemliakh yak dzherelo do istorii formuvannia monastyrskykh bibliotechnykh fondiv, bereznia 04, 2013, [online] http:// www.medievist.org.ua/2013/03/xvixviii.html [retrieved on 23.06.2018]).

Ciborowska-Rymarowycz I., Polonika $w$ księgozbiorze klasztornym karmelitów bosych w Berdyczowie (na podstawie katalogu z 1781 r.). Zarys problemu, "Z Badań nad Książką i Księgozbiorami Historycznymi” 2017, special vol.: Polonika w zbiorach obcych, eds. J. Puchalski, A. Chamera-Nowak and D. Pietrzkiewicz, pp. 229-237.

Ciborowska-Rymarowicz I., Rodovi biblioteky Pravoberezhnoi Ukrainy XVIII stolittia (Vyshnevetskykh - Mnishekiv, Pototskykh, Mikoshevskykh): istorychna dola ta suchasnyi stan, Kyiv 2006.

Cubrzyńska-Leonarczyk M., Polskie superekslibrisy XVI-XVIII wieku w zbiorach Biblioteki Uniwersyteckiej w Warszawie. Centuria druga, Warszawa 2001.

Denysko L.M., Avtografy na knyzhkakh u kolektsii ridkisnykh vydan Natsionalnoi biblioteky Ukrainy imeni V.I. Vernadskogo. Kataloh, Kyiv 2007.

Denysko L.M., Rudakova Y.K., Knyzhkovi znaky na knyhakh iz kolektsii ridkisnykh vydan Natsionalnoi biblioteky Ukrainy imeni V.I. Vernadskogo. Kataloh, Kyiv 2017.

Encyklopedia kościelna podtug teologicznej encyklopedii Wetzera i Weltego, z licznemi jej dopetnieniami, published by M. Nowodworski, Warszawa 1877.

Kachur I., Z historii bibliotek renesansowych - dar Erazma z Rotterdamu dla arcybiskupa Jana Łaskiego, [in:] Książka dawna i jej właściele. Zbiór studiów. Vol. 2, ed. by D. Sidorowicz-Mulak, A. Franczyk-Cegła, Wrocław 2017, pp. 19-34.

Kachur I., Marginalni zapysy yak dzherelo doslidzhennia istorii chytatstva Zakhidnoi Ukrainy XVIII-XIX st., "Zapysky Lvivskoi Naukovoi Biblioteky im. V. Stefanyka" 2008, vol. 1(16), pp. 3-25.

Kachur I., Marginalni zapysy yak dzherelo doslidzhennia retseptsii frantsuzkoi knyhy v Galychyni u 2-i pol. XVIII st., "Bibliotechnyi Visnyk" 2009, vol. 3, pp. 30-34.

Kachur I., Starodruky z bibliotek sanotskoho dukhovenstva u fondakh Lvivskoi naukovoi biblioteky im. V. Stefanyka NAN Ukrainy, "Zapysky Lvivskoi Naukovoi Biblioteky im. V. Stefanyka” 2007, vol. 15, pp. 3-20.

Kataloh paleotipov iz fondov Tsentralnoi nauchnoi biblioteki im. V. I. Vernadskoho NAN Ukrainy, ed. M.A. Shamrai, Kyiv 1995.

Kawecka-Gryczowa A., Biblioteka ostatniego Jagiellona. Pomnik kultury renesansowej, Wrocław 1988.

Kisarauskas V., Lietuvos knygos ženklai, 1518-1918, Vilnius 1984.

Kocowski B., Zadania i metody badań proweniencyjnych $w$ zakresie starych druków, "Przegląd Biblioteczny" 1951, no. 1-2, pp. 72-84. 
Kolesnik E., Knizhnye kollektsii Tsentralnoi nauchnoi biblioteki Akademii nauk USSR, Kyiv 1988.

Kosiński J.A., Propozycja do instrukcji kartoteki proweniencyjnej starych druków, elaborated by M. Pidłypczak-Majerowicz, [in:] Krajobrazy przeszłości. Ksiega ofiarowana doktorowi Adolfowi Juzwence w siedemdziesiata rocznicę urodzin, pod red. M. Dworsatschka, Wrocław 2009, pp. 223-239.

Kurczewski J., Biskupstwo wileńskie od jego założenia do dni obecnych, zawierajace dzieje i prace biskupów i duchowieństwa diecezji wileńskiej, oraz wykaz kosciołów, klasztorów, szkół i zakładów dobroczynnych i społecznych, Wilno 1912.

Laucevicius E., XV-XVIII a. knygu ịrisimai Lietuvos bibliotekose, Vilnius 1976.

Niesiecki K. Herbarz polski [...] powiększony dodatkami z późniejszych autorów, rękopismów, dowodów urzędowych. Vol. 6, published by J.N. Bobrowicz, Lipsk 1841.

Paszkiewicz U., Cathalogus cathalogorum. Inwentarze i katalogi bibliotek z ziem wschodnich Rzeczypospolitej od XVI wieku do 1939 roku. Spis scalony, poprawiony i uzupetniony. [Vol.] 1, Warszawa 2015.

Pidłypczak-Majerowicz M., Badania proweniencyjne $w$ bibliotekach kościelnych, "Fides. Biuletyn Bibliotek Kościelnych" 2014, vol. 20, no. 1, pp. 3-13.

Pidłypczak-Majerowicz M., Biblioteki i bibliotekarstwo zakonne na wschodnich ziemiach Rzeczypospolitej w XVII-XVIII wieku, Wrocław 1996.

Piekarski K., O zadania i metody badań proweniencyjnych. Marginalia do pracy $R$. Kotuli «Właściciele rękopisów i starodruków zbiorów Z. Czarneckiego», Kraków 1929 (duplicate from "Przegląd Biblioteczny" 1929, no. 3).

Pięć wieków ekslibrisu polskiego. Katalog wystawy ze zbiorów Biblioteki Narodowej, elaborated by M. Grońska, Warszawa 1973.

Radziszewski F., Wiadomość historyczno-statystyczna o znakomitszych bibliotekach $i$ archiwach publicznych i prywatnych, tak niegdyś bytych jako i obecnie istniejacych w krajach dawna Polskę składajacych, a mianowicie: w Królestwie Polskiem, Galicji, W. Ks. Poznańskiem i Zachodnich guberniach Państwa Rossyjskiego porzadkiem abecadłowym miejsc ułożona, Kraków 1875.

Roshchyna T., Belaruski superekslibrys: terra incognita, Zdabytki: dokumentalnyia pomniki na Belarusi. Vol. 15, Minsk 2013, pp. 194-203.

Sipayło M., O metodzie badań proweniencyjnych starych druków, “Z Badań nad Polskimi Księgozbiorami Historycznymi” 1975, vol. 1, pp. 9-30.

Skavronski P., "Berdychivska Kolektsiia” knyh v Natsionalnii Bibliotetsi Ukrainy imeni V. I. Vernadskogo 14/06/16, [online] http://berdpo.info/news/kraeznavstvo/berdichivska_kolektsiya_knig_v_natsionalniy_bibliotetsi_ukrayini_imeni_v_i_vernadskogo-id8774.html [retrieved on 23.06.2018].

Słownik geograficzny Królestwa Polskiego i innych krajów stowiańskich. Vol. 2, ed. by F. Sulimierski, B. Chlebowski, W. Walewski, Warszawa 1881.

Strutyńska M., Struktura proweniencyjna zbioru starych druków Biblioteki Uniwersyteckiej w Toruniu. Przewodnik po zespołach. Problemy badawcze i metodologiczne, Torun 1999. 
Trifonova N.Y., O knihach iz biblioteki Glubokskoho karmekitskoho monastyria v sobranii Natsionalnoho khudozhestvennoho museia Respubliki Belarus, Berkovskie chteniia. Knizhnaia kultura v kontekstie mezhdunarodnych kontaktov - 2015. Materialy Mezhdunarodnoi nauchnoi konferencii. Minsk, 26-27 maia 2015, Minsk-Moskva 2015, pp. 548-552.

Wagner A., Ekslibris jako dziedzina grafiki w sferze zainteresowań historii sztuki i bibliologii, [in:] Metodologia, metoda i terminologia grafiki i rysunku. Teoria i praktyka, ed. by J. Talbierska, Warszawa 2014, pp. 95-105.

Wagner A., Superekslibris polski. Studium o kulturze bibliofilskiej i sztuce od średniowiecza do połowy XVII wieku, Torun 2016.

Wanat B.J., Klasztor karmelitów bosych w Berdyczowie na Ukrainie. Studium monograficzne, Kraków 2007.

X.S.Ch. [rev. S. Chodyński], Karmelici bosi w Polsce, [in:] Encyklopedia kościelna podtug teologicznej encyklopedii Wetzera $i$ Weltego, z licznemi jej dopetnieniami. Vol. 10, published by M. Nowodworski, Warszawa 1877, pp. 44-50.

Wittyg W., Ex-libris'y bibliotek polskich XVII i XVIII wieku, Warszawa 1903.

Photo 1. Lviv Discalced Carmelites Monastery's superexlibris. Source: DHC, sign. Berd. coll. 41. Photographer I. Ciborowska-Rymarowicz

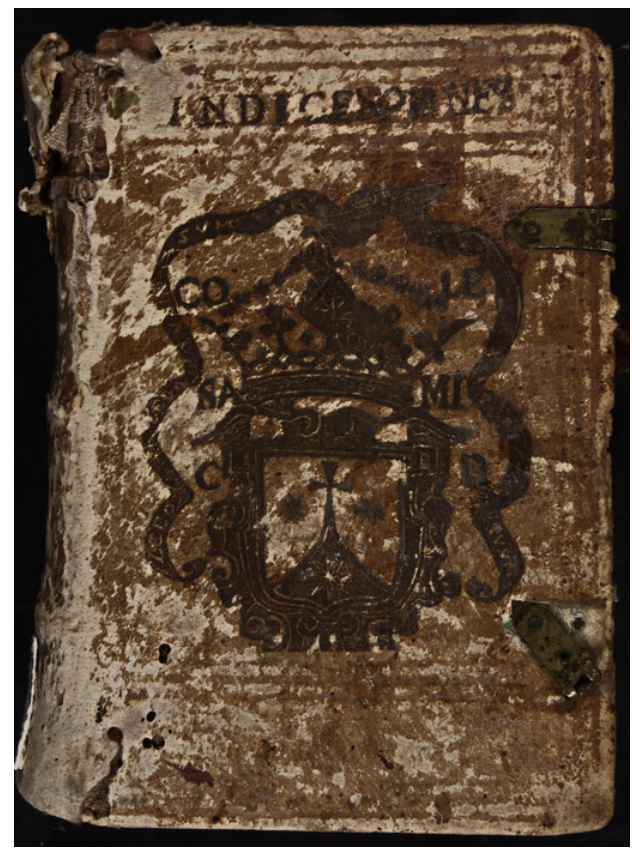


Photo 2. Glębokie Discalced Carmelites Monastery's superexlibris. Source: DHC, sign. Berd. coll. 355. Photographer I. Ciborowska-Rymarowicz

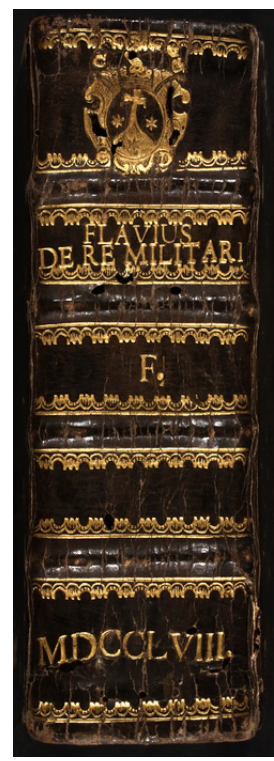

Photo 3. Probably Paweł Orzechowski's superexlibris. Source: DHC, sign. Berd. coll. O/13. Photographer I. Ciborowska-Rymarowicz

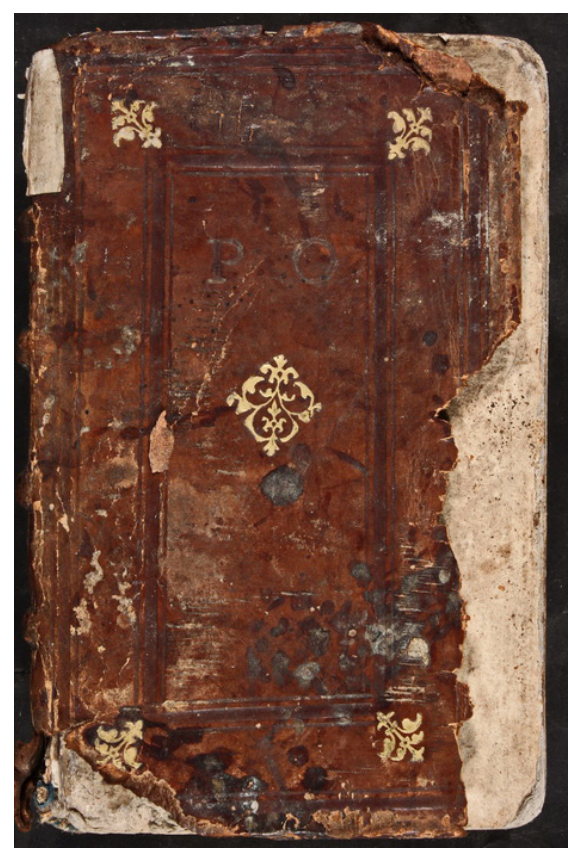


Photo 4. Kyiv bishop J. A. Zaluski’s exlibris. Source: DHC, sign. Berd. coll. 60. Photographer I. Ciborowska-Rymarowicz

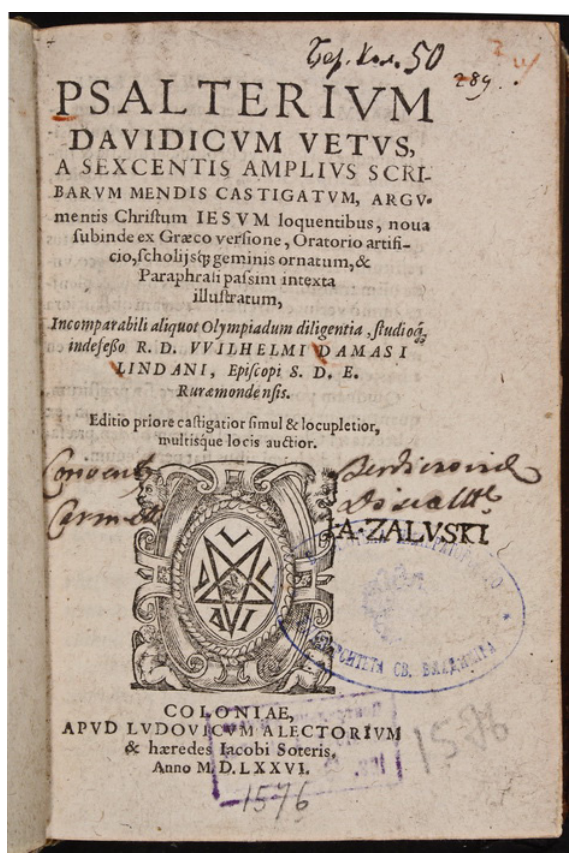

Photo 5. Konstanty Ludwig Plater's exlibris. Source: DHC, sign. Berd. coll. 253. Photographer I. Ciborowska-Rymarowicz

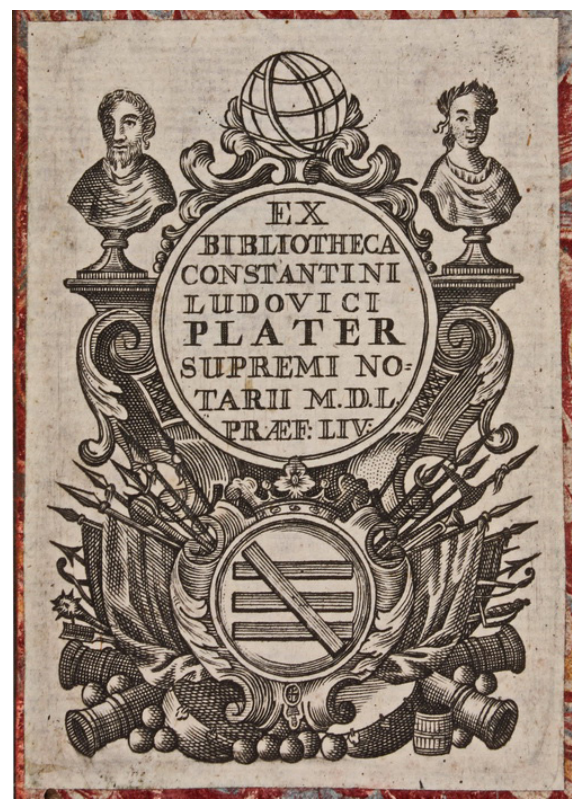


Photo 6. Munchen Jesuits cillege's exlibris. Source: DHC, sign. Berd. coll. 37. Photographer I. Ciborowska-Rymarowicz

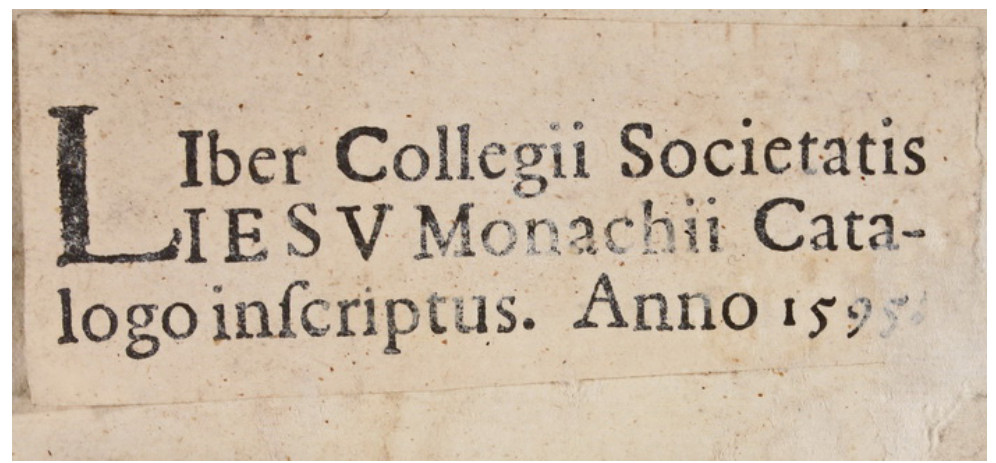

